Submitted to The Australian Surveyor for publication

\title{
Using the Case Study Methodology to Review Cadastral Reform in Papua New Guinea
}

\author{
MARY D. IATAU \\ Graduate Student - ( on leave from Department of Lands, Papua New Guinea ) \\ Department of Geomatics, The University of Melbourne, Victoria, Australia \\ email: iatau@sli.unimelb.edu.au \\ and \\ IAN P. WILLIAMSON \\ Professor of Surveying and Land Information \\ Department of Geomatics, The University of Melbourne, Victoria, Australia \\ email: $\underline{\text { i.williamson@engineering.unimelb.edu.au }}$
}

\begin{abstract}
Cadastral reform is generally considered to be complex, costly, high risk, time consuming and often difficult to introduce. This paper reviews the use of a case study methodology to assess its effectiveness in understanding such reforms.

Current cadastral reform in Papua New Guinea is used in this paper as an example to evaluate the methodology. Case studies in two different provinces are described to highlight PNG's social, political, economic and cultural background and to assess the performance of recent cadastral reform initiatives, particularly with regard to the registration of customary land.
\end{abstract}

\section{INTRODUCTION}

The diverse social and cultural background of Papua New Guinea (PNG), together with its predominant customary land tenure system, have made cadastral initiatives difficult to implement in the country over the years. As a result only about $3 \%$ of the land is officially recorded while $97 \%$ of the land continue to remain under the customary tenure system (Department of Lands, 1996).

Over the last ten years an increase in land and natural resource development, especially on customary land, has highlighted the urgent need to identify an appropriate cadastral system which can facilitate this development. The existing land administration and cadastral system inherited from the Australian colonial administration is inappropriate since it was primarily established to manage and administer only alienated land held under a western tenure system. Recognising the need to reform the system to meet the new demands, the PNG Government commenced the Land Mobilisation Programme (LMP) in 1989. This programme is being undertaken with support and financial assistance from the World Bank (WB) and the Australian Aid Agency (Ausaid) and a grant from the US government.

One of the primary objectives of the LMP is to contribute to improving the national economy, equity and social stability (World Bank, 1989:9). Unfortunately, the desired results are yet to be realised since social and economic instability, land compensation demands, land disputes, environmental damage and uncontrolled land and resource exploitation continue to exist. An example of a major land related conflict which has had an adverse effect on the social and economic stability of the country is the Bougainville crisis.

Nevertheless, benefits and results of cadastral reforms are often intangible and not immediate and can sometimes be achieved over a long period of time. Benefits derived from improved cadastral systems are described by many prominent authors in this field as considerable. Moreno (1984), however, contends that 
a price usually higher than can be afforded by developing countries is often paid for the benefits. High cultural costs are exacted upon these countries, especially where customary tenure is predominant (Ezigbalike and Benwell,1990). The changes imposed upon the cadastral, legal, institutional and organisational infrastructures by cadastral reforms are numerous and complex (Smith, 1990 and Wallace,1990).

This paper supports the premise that cadastral reform such as the LMP are often complex, time consuming, risky and costly. It therefore contends that cadastral reforms and the changes imposed require better planning, coordination, monitoring and management to ensure successful undertaking, particularly in developing countries where resources are usually scarce.

The paper recognises the complexities in understanding existing customary tenures and cadastral reform. It aims to review these systems by applying a rigorous case study technique to assist in understanding some of the issues and possible options for cadastral reform of customary land. The study adopts two LMP customary land registration pilot areas as case studies. A further objective of the paper is to assess how effective the case study methodology is in understanding these complexities.

\section{APROPRIATE AND EFFICIENT CADASTRAL SYSTEMS}

As outlined above, PNG's cadastral system is not serving its national objectives. James (1985:164) describes the policies derived from the national goals in the preamble of the Constitution as "the sharing of economic improvement among all people of PNG, the wise use and conservation of the land and other natural resources, and development through PNG social and economic forms". The existing cadastral system is considered to be inappropriate. It is therefore necessary for some discussions on what constitutes an appropriate cadastral system and its role in the context of national development.

Land policies are usually part of national, state and provincial policies and generally relate to economic development, issues of equity and aim to support social and political stability. Land administration can be considered to be the functions involved in implementing land management policies. The cadastral system in turn is an integral part of the land administration system and is a fundamental tool through which land administration and in turn land policies are realised.

The cadastral system comprises a land registration system on the one hand and a cadastral survey and/or mapping system on the other. The central components of the cadastral system are adjudication, demarcation, survey, preparation of boundary descriptions and survey specifications. Cadastral maps, title and boundary records, and valuation, taxation, planning and development information are described as the output elements of the cadastral system (Dale, 1976:36).

Effective administration and management of land is almost impossible without land information. The cadastre is the primary means of providing information about land such as location, size, value, use, improvements, owners and occupiers, and the rights, responsibilities and restrictions relating to land. This concept is further explained in the International Federation of Surveyor's 'Statement on the Cadastre' (FIG, 1995), which defines the cadastre as "a parcel based and up-to-date land information system containing a record of interests in land". The Statement also describes many of the available options in establishing an effective and efficient cadastre.

Ezibalike and Benwell (1990:381) emphasis that cadastral systems should be an information base. They argue that most resources for management in developing countries are land-based and that cadastral information should not be restricted to tenure and ownership information only. It should also include various other information about land.

The Bogor Declaration (UN, 1996) also proposed that a cadastral vision of the future was "....to develop modern cadastral infrastructures that facilitate efficient land and property markets, protect the land rights of all and support long term sustainable development and land management". Williamson (1997) supports this view and further suggests that cadastral systems designed for less developed countries should be 
"simple, flexible, freely accessible and low cost, and have similarities with the systems supporting the operation of informal land markets". He further states that this system should permit incremental development within an overall land information strategy. This view on progressive cadastral systems which are of simple, sound design, suited to the local conditions and readily adaptable to further modification is also supported by Doebele (1985) and Larsson (1991:145-153).

Efficient and appropriate cadastral systems are fundamental in ensuring economic

development, social stability and environmental management (UN, 1996 and Williamson, 1997). Furthermore special emphasis has been given to customary tenure regarding developing countries. For example, the Bogor Declaration states that:

....(cadastral) infrastructure should support a vast array of legal, technical, administrative and institutional options in designing and establishing an appropriate cadastral system, providing a continuum of forms of cadastre ranging from the very simple to the very sophisticated. Such flexibility allows cadastres to record a continuum of land tenure arrangements from individual land rights through to communal land rights, as well as having the ability to accommodate traditional or customary land rights.

Accepting the above broad criteria as to what constitutes an appropriate and efficient cadastral system, the following case study methodology is used to review of the performance of the PNG system to assist in designing the most suitable system.

\section{THE CASE STUDY METHODOLOGY}

An important objective of this paper is to evaluate the effectiveness of the case study methodology while using it to understand "how" and "why" the PNG cadastral system operates and interacts with local conditions. It is not aimed at solving all of PNG's cadastral problems but to provide some understanding of the existing conditions; to make some comparisons between different jurisdictions to enhance understanding; and, to identify strengths and weaknesses before recommending any solutions.

Considering the complexity of cadastral reforms, this paper argues that research and rigorous study should be an important early component of every cadastral reform. Problematic areas of cadastral systems and reforms should be identified and examined in more detail through case studies to enable better understanding and to be able to identify appropriate solutions. Recognising the relationship between anthropological and cadastral studies, Williamson and Fourie (1997) describe this concept in more detail and suggest that anthropological methods of case study be adopted to sharpen the frontiers of cadastral studies. It is with this focus that this study adopts an anthropological case study technique to understand the complexities in cadastral reform and customary tenures.

The case study methodology adopted for this study is user (stakeholder) focussed and recognises the significance of user involvement described by Latu et al. (1996). However, Latu et al. describes the users involvement from an information systems development viewpoint while the cadastral reform methodology is an application of an anthropological classification of case studies as described by Williamson and Fourie (1997). The latter approach incorporates the basic components as shown in Figure 1.

The research described in this paper concentrates primarily on the first component of the cadastral reform methodology. It also includes the first part of the second component, basically to enable some comparisons of the case study areas. The subsequent sections of this paper describe each of the parts of the methodology as used to review PNG's land administration and cadastral reform 
and to be able to identify appropriate solutions. Recognising the relationship between anthropological and cadastral studies, Williamson and Fourie (1997) describe this concept in more detail and suggest that anthropological methods of case study be adopted to sharpen the frontiers of cadastral studies. It is with this focus that this study adopts an anthropological case study technique to understand the complexities in cadastral reform and customary tenures.

The case study methodology adopted for this study is user (stakeholder) focussed and recognises the significance of user involvement described by Latu et al. (1996). However, Latu et al. describes the users involvement from an information systems development viewpoint while the cadastral reform methodology is an application of an anthropological classification of case studies as described by Williamson and Fourie (1997). The latter approach incorporates the basic components as shown in Figure 1.

The research described in this paper concentrates primarily on the first component of the cadastral reform methodology. It also includes the first part of the second component, basically to enable some comparisons of the case study areas. The subsequent sections of this paper describe each of the parts of the methodology as used to review PNG's land administration and cadastral reform

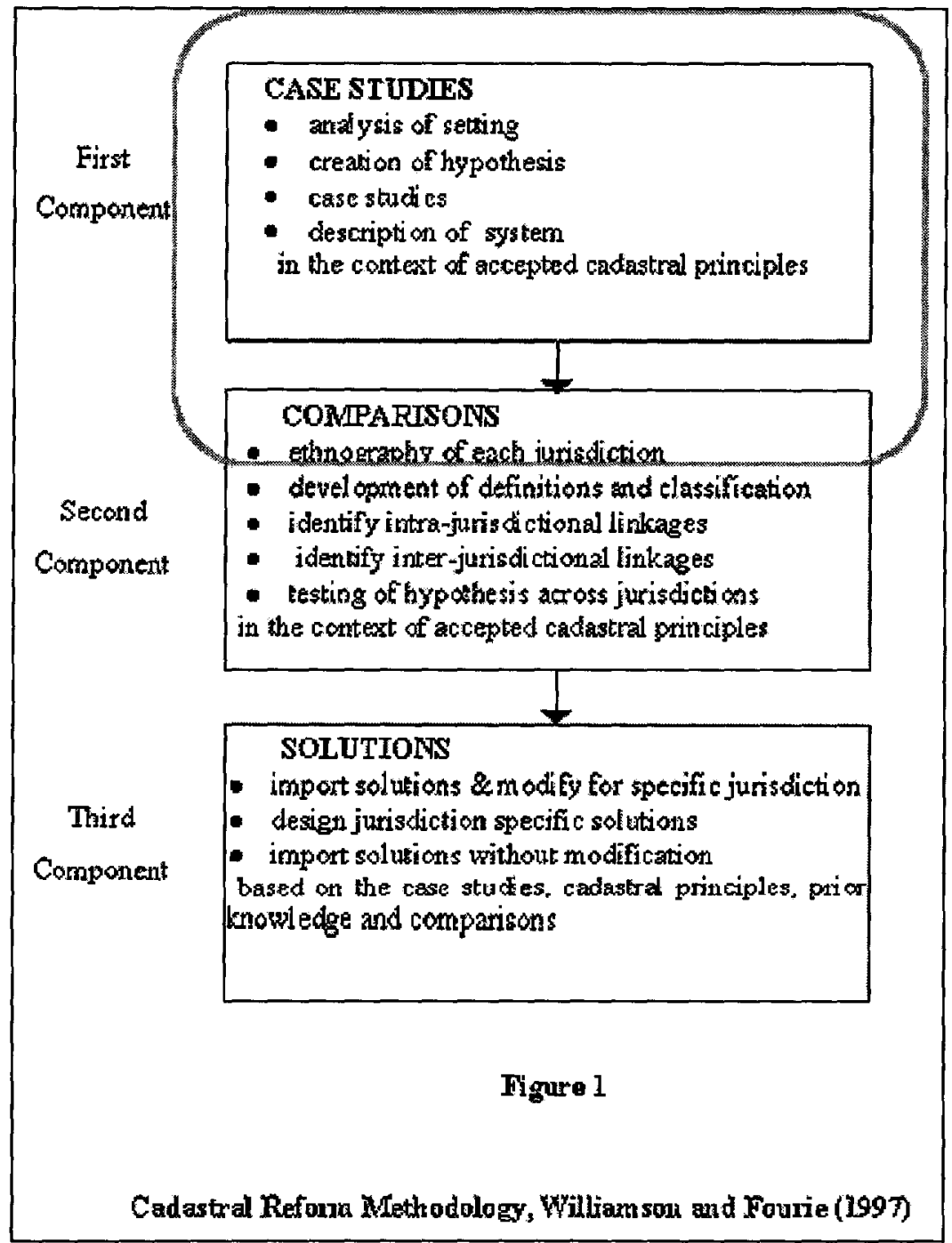

Cadastral Reform Methodology (Williamson and Fourie, 1997) ANALYSIS OF THE SETTING OF PAPUA NEW GUINEA 
Cadastral Reform Methodology (Williamson and Fourie, 1997)

\section{ANALYSIS OF THE SETTING OF PAPUA NEW GUINEA}

\section{Introduction}

The analysis of the setting is the first step in the cadastral reform methodology. The setting comprises a brief ethnography of PNG, its cadastral system and the LMP. By reviewing and analysing the setting and considering the social and economic factors in the light of cadastral principles and context, the authors believe certain problematic areas may be highlighted and identified for research and study.

Ethnography is described by Hammersley and Atkinson (1983:1-2) as a description or a form of storytelling of a particular community or society often produced by ananthropologist based on "raw" data collection. They describe ethnography as the source through which meanings that give form and content to processes can be understood. In considering the significance of ethnography, this study attempts to compile a brief ethnographical analysis. This analysis is not necessarily from 'raw' field data collection but from reviewing literatures on PNG prepared by anthropologists in conjunction with recent field observations. Ethnographical analysis of both the general setting of PNG and the case study areas of East New Britain (ENB) and East Sepik (ES) provinces are described in subsequent sections.

\section{Brief Ethnography of PNG}

With a population of about 3.5 million people (1985 census) spread over a total land area of 462,840 sq.km and having about 750 different languages (Schroeder, 1992), PNG exhibits great diversity in 
customs and cultures. James (1985:2) describes PNG's major problem as, "...to maintain its unity and at the same time preserve, as the Constitution requires, a respect for the traditional culture of the various communities, and overcome divisive tendencies which threaten its nationhood".

The $80 \%$ of the population who live in the rural areas are sustained by subsistence farming whilst those in the urban centres depend mostly on formal employment. However, recent natural resource extraction activities particularly in mining and logging have rapidly changed people's lives in the affected areas from the traditional subsistence economy to a cash economy. In other areas, the change is effected by the transition from traditional subsistence farming to large scale cash cropping. The western market economy is increasingly impacting on PNG.

Administratively the country is divided into 20 provinces, with administrative functions implemented both centrally and provincially. The provincial government system, which is meant to bring services closer to the people, has proved to be inadequate. Almost half of the 20 provincial governments have been suspended at one time or another for misappropriation of funds or ineffectiveness (James, 1985:11). Nevertheless, in more recent times there has been an attempt to improve the provincial governments through the New Organic Law (No.16 of 1995) on Provincial and Local Level Governments to ensure that services get to the people.

PNG has a dual land tenure system; the adopted western tenure systems of leasehold and freehold and the customary tenure system. The former system is based on written legislation and is concerned about the management and administration of alienated land. This currently comprises about $3 \%$ of the land. The other $97 \%$ is held under the customary tenure, according to unwritten laws, principles, customs and practises commonly accepted by the people. Land ownership and usufructuary rights may vary from place to place. Nevertheless, rights are recognised universally through kinship groups. By this method subsistence security is is also provided. Any changes to the tenure of customary land can be a very sensitive issue as $85 \%$ of Papua New Guineans depend on it for their basic needs ( food, water and shelter ) for survival.

Increasing demands for land for economic development indicates a need for customary land to be made available and to be brought into the cadastral system. On the contrary, the need for and the significance of the role of customary land as the source of livelihood highlights the controversy as to whether customary land should be registered or not. The modern development and market forces pressing on the customary tenure highlights the need for rigorous study to identify what is the appropriate or optimum system for a basically traditional society transiting under pressure from a modern market economy.

\section{The Cadastral System in Papua New Guinea}

PNG inherited its cadastral system from Australia. This system is based on the Torrens title registration system, but operates only over a small percentage of land under the Land Registration Act 1981. Registered titles under this system are legally indefeasible and a government guarantee is provided to compensate current title holders for any loss through forgery or fraud, thus providing a high level of security and certainty of ownership (Turtle, 1991: 87).

On the other hand, the inherited Torrens system reflects some of the deficiencies pointed out by Dale (1990) and needs to be modified. The deficiencies include the inability to handle multiple ownerships of single parcels of land especially with shares in the land; to cope with ownership of high rise flats and apartments (strata titling); and to record forms of customary tenure and over-riding interests. Other countries have appropriately accommodated these deficiencies by modifying their systems however PNG has yet to introduce such changes.

The 3\% alienated land comprises a total of 117, 673 parcels of which 106, 892 are held as leasehold, 4,224 as freehold and 6,557 as registered customary land (Department of Lands, 1996). Turtle (1991:88) estimated 100,000 of these parcels to be registered as 'subject to survey', meaning that they are only described with approximate boundaries and are yet to be surveyed. Such surveys are often carried out 
using chain and compass due to lack of trained surveyors. The high costs and time constraints in acquiring accurate surveys is also a limiting factor. Recognising this need, the Surveyor General made provisions for the Rural Class 3 surveys in the 1980 Survey Directions to integrate chain and compass surveys into the cadastral system, particularly to meet the needs of the rural sector. Nevertheless, most surveys, particularly those in urban areas have been carried out to a relatively high accuracy.

The Department of Lands (DOL) has been the central government body responsible for land administration and the operation of the cadastral system. There are recent moves to decentralise these functions through the provincial government system. The primary function of the DOL is administering the alienated freehold and leasehold land held under the Torrens system. The DOL also facilitates the conversion of customary land to freehold and leasehold titles in conjunction with the Land Titles Commission and the Department of Provincial Affairs. However the need to extend DOL's traditional function to include the management and administration of customary land becomes inevitable. Shortage of alienated land for national development; excessive land compensation demands by customary land owners; inadequate involvement of customary land owners in economic development; and, no control, coordination and monitoring of dealings on customary land by landowners and developers, are some of the problems highlighting this need.

It is therefore necessary to formalise or document customary tenure since without information it will be impossible to effectively administer and manage customary land. As mentioned earlier the cadastre is the primary means through which information about land is collected and recorded.

However, registration of customary land has always been a controversial and sensitive issue for decades in PNG. The recent unanimous opposition and rejection to the Customary Land Registration Bill (1995) demonstrates the importance of people's attachment to land. The general population are always suspicious about the government's move to register customary land. The common fear is always that of landlessness without realising that the government has established numerous policies to protect indigenous land owners. Instead they should fear speculation of their land by certain privileged indigenous people, which Bruce (1988:40) describes as powerful, wealthy and can move fast to accumulate land at the expense of others.

The Land Groups Incorporation Act (Chapter 147) was introduced to stop such individuals taking advantage of traditional owners by gaining access to communal land. This legislation permits land to be registered under a group title rather than an individual registered proprietor. Commonly, customary land is registered by utilising the Land Group Incorporation Act (Chapter 147) (LGIA), Land Tenure Conversion (LTCA) Act, 1963 and Lease Lease Back Scheme (LLBS). The LTC enables the tenure of customary land to be converted to freehold tenure while the LLBS converts tenure of customary land to leasehold tenure for a specified period of time. The State acquires the land from the customary owners and then leases it back to them for development or to subleases it to others.

Nevertheless, in both processes, the bureaucratic and administrative bottlenecks within the cadastral system and the associated infrastructure are a major limitation. The above issues and the inflexibility of the existing title registration system suggest the existence of a slow, inefficient, inappropriate and out of date cadastre and land administration system. This highlights the need for reform and improvement.

\section{A Review of the Land Mobilisation Program}

Recognising the inefficiencies in the existing land administration system, and the existing cadastral problems, the PNG government, with funding and support by World Bank(WB) and Australian Aid Agency (Ausaid), commenced the Land Mobilisation Programme (LMP) in 1989. The LMP grew out of the Land Administration Improvement Program (LAIP) which began in 1984. Subsequently, it led to the Land Evaluation and Demarcation Project (LEAD Project) in 1987 and finally to the LMP in 1989. Total costs for the first five years of the LMP, starting in 1989, were estimated as US\$46.8 million. As a result of a review of the project after 5 years, the project was extended for a further three years. 
The main objective of the LMP is "To contribute to economic growth through more productive use of land resources throughout the country, whilst promoting equity, employment, participation and social stability." (World Bank Report No. 7592-PNG, 1989: 9). The LMP comprises six main components:

1. Program management

2. General Institutional building

3. Mobilising alienated land

4. Mobilising customary land

5. Decentralisation of alienated land administration

6. Land and Resource Information

The focus of this study is centred around the fourth component of the LMP. The most significant initiative undertaken as part of this component is the drafting of the framework legislation for customary land registration in 1995. As stated this legislation was unanimously opposed and rejected by the people. Also as stated most of the problems highlighting the need for reform were due to activities occurring on customary land. However any initiative to register customary land is opposed by the people, so the question now is; what is appropriate, achievable and acceptable to the people?

This study adopts two of the LMP pilot areas of registration of customary land as case studies to review the local conditions influencing the customary land registration process to find some possible answers to the above question. The case studies as described in the subsequent sections of this paper review the implementation of LMP from a social, cultural, geographic, administrative, legal, and economic perspective. Data collected for these case studies focussed mainly on the hypothesis created for the study. The creation of the hypothesis is the second part of the cadastral reform methodology.

\section{HYPOTHESIS CREATED FROM THE REVIEW OF THE SETTING}

By analysing and reviewing the setting, which in this case, is PNG's ethnography, cadastral system and the LMP, it is recognised that PNG's social and cultural life is being considerably impacted by the transition to a cash economy. Extensive land information is required to be able to solve land related problems and to efficiently manage land and land related resources. Therefore the need to identify an appropriate and acceptable cadastral system to administer all tenure arrangements is critical and urgent.

In accordance with the methodology, having identified customary land registration as the problem area, it is necessary to define the boundaries of the case study to encompass only a certain perspective of the problem area to allow for rigorous study. The boundaries are defined by creating a hypothesis, such that field data collected for the case studies can be aimed at proving or disproving the hypothesis. Hence, the hypothesis for this study is:

\section{A simple, progressive, well organised, timely and effective cadastre and land administration system, which includes customary land, and is aimed at eliminating all procedural and legislative flaws, is necessary to successfully realise and implement national economic, environmental and social policies.}

This study focusses on the existing legislations of Land Group Incorporation Act, Land Tenure Conversion Act and the Lease Lease-Back Scheme which facilitate the sporadic registration of customary land. As these legislations are generally accepted by the people they need to be developed to provide more efficiency and effectiveness. The study assumes that there are procedural and legislative flaws or gaps in the administrative and cadastral infrastructure. These flaws need to be identified and eliminated to fully support efficient registration of customary land.

Having established the hypothesis, the next step is to either prove or disprove it. This requires focused field data collection. Data collection is a very important component of such a study as it is the very basis of the case studies. 
For this study, the first author (Ms.Iatau) spent six weeks in the LMP pilot areas, interviewing and interacting with stakeholders. Questionaries and interview questions were designed with the assistance of Dr. Clarissa Fourie, an anthropologist with extensive background in informal settlements in the South African cadastre (Fourie and van Gysen, 1994 and Williamson and Fourie, 1997). Raw field data was collected from informal interviews as well as structured interviews with specific stakeholders.

Stakeholders included surveyors, land developers, lawyers, land administrators, local land court mediators and consultants on the various cadastral reform projects. Policy makers such as provincial planners, managers and assistant secretaries were also interviewed. Most importantly, views and opinions of village elders, members of incorporated land groups, individuals and members of the public were also obtained and documented. This data gave a good indication of the understanding by the community of the underlying issues related to the registration of customary land and the cadastral system.

\section{CASE STUDIES AND DESCRIPTION OF THE PROVINCES}

The case studies presented in this paper describe the different initiatives being undertaken to register customary land in the two LMP pilot provinces. Fourie and van Gysen (1995) and, Williamson and Fourie (1997) argue that a researcher undertaking a case study should consider technical, administrative and socio-economic factors and socio-political behaviour associated with the cadastral system, in order to understand the local conditions and circumstances surrounding cadastral reforms. This was attempted for these case studies.

\section{East New Britain Province Case Study}

Located on the circum-Pacific volcanic zone on the island of New Britain, which is to the east of the main island of New Guinea, the East New Britain Province (ENBP) comprises a population of 90,000 people (1980 Census). Three indigenous languages, namely the Kuanua, Bilur and Duke of York are spoken by the people (Fingleton, 1985). The province is supported by a high yield of the main cash crops of copra and cocoa which is due to the richness of the soil as a result of regular volcanic activity .

People who come from the ENBP are generally known as the Tolais. These people practise a matrilineal system of land holding like most of the other smaller islands in PNG including New Ireland, Bougainville and Manus. Rights to land are recognised and held communally through kinship groups. Female members of the group are land owners and they make decisions concerning land in consultation with the rest of the kin members. Land ownership and usufructuary rights are inherited from mothers. This system is known as Vunatarai and means a group whose members trace their matrilineal descent from a known common female ancestor or ancestors. However Karani (1995) pointed out that patrilinealism is also practised in a few areas.

Fingleton (1985) in his extensive study of the Tolai people explained that the tenure to any parcel of Tolai land cannot be understood except within the historical framework of emerging social and political relationships. Land holding is through kinship groups, these groups being identified with a particular locality. In other words the identification is derived from historical connection with the land. He pointed out that the influence of big men (village elders) and sorcerers (witch doctors) in the villages threaten the security of a person's tenure. To ensure security of tenure Tolais maintain their kin relationships by actively participating in ceremonial activities and through day to day social interaction.

Fingleton (1985) further identified the two processes by which tenure was changing. Firstly the spontaneous process and secondly, the prescriptive or legislative process. He pointed out that the latter process is usually undertaken as a precursor to economic development. The legislative process has minimal effect and is often at considerable social cost. However, the spontaneous process is a natural process as people respond to the changing social, political and economic environment. He recommended that this should be facilitated for adaptation. James (1985:21) also acknowledges this by saying that, "Traditional law is itself flexible and could change to accommodate the changing circumstances". 
The most significant development in cadastral reform with regard to customary land is the creation and implementation of the Customary Land Management System (CLMS). The CLMS is an initiative by the Tolais themselves in which their local youths are trained to carry out demarcation and adjudication using simple compass and chain surveying techniques. The Tolais are seen to be initiating the replacement of the informal, unwritten system with formal recording of land tenure. Karani (1995) stated that land tenure based on memory was becoming unreliable. This is due to constantly changing political and social structures.

Another factor identified during the field study that could have triggered the formal recording of tenure is the change in topography and the disappearance of natural features as a result of the 1994 volcanic eruption. The main Rabaul township and the surrounding areas, including traditional boundary marks such as creeks, waterways, mountains, ridges and plants, were buried under volcanic ash and lava.

Nevertheless, to register the land formally, the Land Titles Commission (LTC) is still the only legal body in the country through which land hearings are made and approved for registration. The LTC being a centralised process appears to be a major constraint to the process of registration of customary land.

ENBP in the past few years has been one of the few provinces actively striving to establish a geographic information system (GIS) as a tool to assist in its initiatives to improve the efficiency in land and resource management. The use of the Global Positioning System (GPS), remote sensing and aerial photography have been trialed for cadastral applications. The local people are aware of the necessity to have accurate land information as a pre-requisite to better land and environmental management as a base for sustainable development.

However, certain risks are often taken when adopting modern technology for usage in developing countries. The most common risk is the unavailability of local expertise to successfully implement and maintain the system. Initiatives driven by expatriate knowledge without consideration of this factor can be costly and a waste of time and resources.

\section{East Sepik Province (ESP) Case Study}

The East Sepik Province (ESP) is located towards the north eastern part on the main island of New Guinea. Its geographical structure comprises reasonably flat and swampy areas surrounded by marsh grassland in some parts and in others with mangroves and sago patches. This description applies to areas towards the coast and areas near the river systems such as the Sepik River. Land further inland, towards the Prince Alexander Range, is described as rugged, mountainous and covered with tropical rain forest.

The ESP is inhabited by the racial group commonly known as the Sepiks who speak at least 214 languages out of the estimated 750 languages of PNG (Schroeder, 1992). The social structure of the Sepiks is simple and highly flexible. The family comprises a man, his wife or wives, and his and their children. The village is the largest and the most important political unit.

Land holding is recognised through kinship groups and more specifically through patrilineal lines as commonly practised in most areas of the main island of New Guinea. Land ownership and rights to land are commonly held by male members of the family which are then inherited by other male members, especially the eldest upon death. Unmarried, widowed female members or other members who prefer to remain in their own village can also inherit rights to land but the normal practise is that after marriage females are expected to live in their husband's village.

The ESP's relative isolation and the perceived comparative economic advantage of other areas has resulted in very little land being alienated to the state and subsequently leased out for agricultural purposes (Power, 1991:101 and Fingleton, 1991:149). Consequently most agricultural produce comes from small holder planting and subsistence farming of customary land. As a result of becoming more conscious of the value of their land, villagers prefer to be involved in the development of their land rather 
than allowing the state to acquire land for development. Recognising the need to assist the customary land owners to develop their land and the overall development of villages as part of modern PNG, the provincial government initiated, through the LMP, the country's first ever provincial land legislation in 1987.

Power (1991:101), the ESP's provincial planner at that time, described a number of reasons for the need of new legislation. These included national inactivity, the ineffective centralised cadastral system, linguistic diversity and the major regional differences. The major linguistic diversity in particular interfers with discussions and decisions resulting in consensus. The new legislation incorporates the regulation of dealings and the provision for mortgages over unregistered customary land and provides for registration of customary land through the key mechanism of incorporated land groups.

As a result of this legislation, several joint venture projects were initiated. These included the Kreer Housing Project, Frieda River Mining Development, Among Guest House on Muschu Island, Kambamba Acquatic Lake Project, Wewak Angoram Land Development Project and many others. In spite of the land owners' enthusiasm to be part of development, there appeared to be a general break down in the administrative processes, resulting in a lack of coordination and monitoring of the progress the projects.

In addition to the cadastral and administrative inefficiencies in providing land titles, bottlenecks were created by non-compliance resulting in unfulfillment of agreements between land owners and joint venture partners. Other problems involved non co-operation between departments and organisations involved in the projects. This was partly due to changing of key and senior office holders. Examples of problems encountered in establishing some of these projects are also described by Power (1991:110).

The Kreer Housing Project is a good example of a joint venture which has not been successful. After subdivision and construction of roads by the Housing Corporation, the joint venture partners of the Kreer housing development scheme failed to complete building other infrastructure. For some unknown reason the project was abandoned. Interviews with the manager of the Housing Corporation revealed the manager's lack of knowledge of the details of the project since taking over from his predecessor. Similarly, the new provincial planner indicated that he had little knowledge of the project.

At the time of field data collection for this study, PNG was in the midst of the World Bank's structural adjustment programs and the general views expressed by most stake holders were that of uncertainty. The transfer of centralised functions and related funds to the provincial and local level governments were seen to be the cause of confusion and uncertainty. The need for careful strategic planning in any major legal, administrative and socio-economic reform, which includes cadastral reform is anessential pre-requisite.

\section{CONCLUSIONS}

Preliminary evaluation of the two case studies indicates differences in approach to registration of customary land at a decentralised level. The different approaches are seen as a reflection of the social, political, legal, economic and geographic backgrounds of the peoples within the two study areas.

The ENBP initiatives are being driven by the people themselves with the support from the provincial government whilst the ESP initiative is driven by the provincial government which has set up the supportive political and legal infrastructure. Despite some achievements, both case studies indicated slow and inefficient provision of title documents by the LTC through the DOL. Therefore, it is considered that in order to support such provincial initiatives, it is essential for the operation of the Land Titles Commission to be decentralised. The review also suggest that costs, time and risks associated with the LMP can possibly be minimised if reform initiatives are better planned, co-ordinated, monitored and managed.

Initial assessment of the cadastral reform case study methodology adopted in this study demonstrates that it is successful. The methodology enables a researcher to understand why certain things happen. The process is objective and focuses on solving a specific cadastral problem. Whilst reviewing the setting, a 
researcher might also identify other problems which may lead to further case studies, so in reality, problems are addressed one at a time. This is important in gaining a full understanding of the complexities of customary land tenure and associated cadastral reforms.

\section{ACKNOWLEDGEMENTS}

The authors wish to thank AusAid, the PNG Government and the University of Melbourne in supporting this research. Dr. Ezigbalike and Dr. Holmes are also acknowledged for their contribution and valuable comments on this paper.

A earlier and shorter version of this paper was presented to the International Federation of Surveyors (FIG) Symposium on Cadastre and Land Management symposium run in conjunction with the $64^{\text {th }}$ Permanent Committee of the FIG in Singapore on the 11-16th, May, 1997.

\section{REFERENCES}

Bruce, J.W., (1988), ìA Perspective on Indigenous Land Tenure Systems and Land Concentrationî, Downs and Reyna 1988, 23-52.

Dale, P.F., (1990), "Cadastral Reform '92 - Let the Users Speak", Proceedings of the International Conference on Cadastral Reform '92, Melbourne, Australia, 29 June -1st July, 1992, 1 - 6.

Dale, P.F., (1976), "Cadastral Surveys within the Commonwealth", Overseas Research Publication No.23, Her Majesty's Stationery office, London.

Department of Lands, (1997), Personal Correspondence with Phil Isaacs (Manager - Land Information Unit).

Doebele, W., (1985), iWhy cadastral systems are important for less developed countries, The Urban Edge, 9 p.

Ezigbalike, I.C., and Benwell, G.L., (1990), iCadastral iReformî,- What they never tell you about the cultural costsî, Proceedings of the International Conference on Cadastral Reform ë92, Melbourne, Australia, 29 June -1st July, 1992, 368 - 383.

FIG, (1995), "Statement on the Cadastre", International Federation of Surveyors, Canberra, FIG Australian Bureau 1992 - 95, Canberra, 22p.

Fingleton, J., (1991), ìThe East Sepik Land Legislationî, Monograph 29, Customary

Land Tenure: Registration and Decentralisation in Papua New Guinea, National Research Institute publication, Port Moresby, Papua New Guinea, 147-162.

Fingleton, J., (1985), ìChanging Land Tenure in Melanesia: The Tolai Experienceî, PHD Thesis, Australian National University.

Fourie, C. and van Gysen, H., (1995), iConstructing Cadastral Reform Theory in South Africaî, Geomatica, 49(3): 315 - 328.

Hammersley, M. and Atkinson, P. (1983), iEnthnography Principles in Practice, Travistock, London.

James, R.W., (1985), iLand law \& policy in Papua New Guineaî, Monograph No.5, Law Reform Commission of Papua New Guinea, 204 p.

Karani, P.W., (1991), ìmplementing the Customary Land Management System Manualî, Unpublished, 
Rabaul, Papua New Guinea, 12 p.

Larsson, G., (1991), ìLand Registration and Cadastral Systemsî, Longman Group UK Limited.

Latu, S., Benwell, G., and Davies, P., (1996), iPart 2: User Involvement: The Tongan Land Informaion Systemî, The Australian Surveyor, Sept. 1996, p.204-213.

Moreno, R., (1984), ìCadastres and Land Registrationî, Proceedings of the International Workshop on Land Tenure Administration, p.409-416

Power, T., (1991), "Policy Making in East Sepik Province", Monograph 29,

Customary Land Tenure: Registration and Decentralisation in Papua New Guinea, National Research Institute publication, Port Moresby, Papua New Guinea, 101-120.

Schroeder, R., (1992), "Initiation and Religion: A Case Study from the Wosera of Papua New Guinea.", University Press Fribourg Switzerland.

Smith, G.L., (1990), "Cadastral Reform: Barriers, Risks and Opportunities", In the Proceedings of the XVIX FIG Congress, Helsinki, Vol.7, 283-294.

Turtle, C., (1991), "Administrative Reform and Land Mobilisation", Monograph 29, Customary Land Tenure: Registration and Decentralisation in Papua New Guinea, National Research Institute publication, Port Moresby, Papua New Guinea, 87-100.

United Nations, (1996), "The Bogor Declaration", Report from the United Nations Inter-regional Meeting of Experts on the Cadastre, Bogor, Indonesia, 18-22 March, 1996, International Federation of Surveyors, $\mathrm{UK}, 10 \mathrm{p}$.

Wallace, J., (1990), "Barriers to Cadastral Reform", Proceedings of the International Conference on Cadastral Reform '92, Melbourne, Australia, 29 June -1st July, 1992, 192-200.

Williamson, I.P (1997), "The Justification of Cadastral Systems in Developing Countries", Geomatica, Vol 51, No 1, 1997, pp 21-36.

Williamson, I.P., and Fourie, C., (1997), "Using the Case Study Methodology for Cadastral Reform", Submitted to Geomatica, $17 \mathrm{p}$.

Williamson, I.P., (1986), "Cadastral and Land Information Systems in Developing Countries", The Australian Surveyor, Vol 33, No 1, 27-42.

World Bank, (1989) "Staff Appraisal Report", Land Mobilisation Project, April 12,1989, Report No. 7592-PNG, Department of Lands, Port Moresby, Papua New Guinea. 106 p.

\section{BIOGRAPHICAL NOTES}

\section{Mary D. Iatau}

\section{Grad.Dip. ITC., B. Tech. PNGUT}

Mary Iatau is currently a Master of Applied Science Student in Geographic

Information Systems at the University of Melbourne. Iatau completed a Graduate Diploma in LIS/GIS in Cadastral Applications at the International Institute of Aerospace Survey and Earth Sciences (ITC) in The Nederlands in 1993. Prior to this she graduated with a Bachelor of Technology in Cartography from the Papua New Guinea University of Technology in 1987. She is a member of the PNG Institute of 
Cartographers. Iatau has since been employed by the Department of Lands, in Port Moresby, Papua New Guinea, first as a Senior Survey Draftsperson in the Land Administration Section and later in the Land Information Unit (LIU) as a Computer Operator, Senior Programmer and then Systems Analyst. Prior to undertaking her current studies she was involved with the Analysis and Design of the PNG Land and Geographic Information System. Her current interests include the modelling and designing of LIS / GIS for developing countries with traditional tenures and the improvement of the land administration and cadastral system through the use of LIS technology.

\section{Ian P. Williamson}

\section{PhD (NSW), FISAust, FIEAust, Registered Surveyor, CPEng}

Professor Williamson holds the Chair of Surveying and Land Information in the Department of Geomatics at the University of Melbourne, Australia. He holds bachelors, masters and doctorate degrees in Surveying and is a Registered Professional Surveyor and a Chartered Professional Engineer. He is both a Fellow of the Institution of Surveyors, Australia and the Institution of Engineers, Australia. Prior to his academic career, he worked in a state government in Australia, an American engineering corporation based in the USA and ran his own consultancy practice in Sydney. He is Chairperson (1994-98) of Commission 7 (Cadastre and Land Management) of the International Federation of Surveyors. His interests are in the operation, management and development of land administration systems with particular emphasis on cadastral, land and geographic information systems.

Internet: i.williamson@,engineering.unimelb.edu.au. 


\section{University Library}

\section{- M M I E E R VA A gateway to Melbourne's research publications}

Minerva Access is the Institutional Repository of The University of Melbourne

Author/s:

latau, Mary D.; Williamson, Ian P.

Title:

Using the case study methodology to review cadastral reform in Papua New Guinea

Date:

1997

Citation:

latau, M. D., \& Williamson, I. P. (1997). Using the case study methodology to review cadastral reform in Papua New Guinea. The Australian Surveyor, 42(4), 157-165.

Persistent Link:

http://hdl.handle.net/11343/34002 